\title{
Solvent Sublation and Spectrometric Determination of Iron(II) and Total Iron Using 3-(2-Pyridyl)-5,6-bis(4-phenylsulfonic acid)- 1,2,4-triazine and Tetrabutylammonium Bromide
}

\author{
Magda Ali AKL, ${ }^{* \dagger}$ Yoshihito MorI,** and Kiyoshi SAWADA*** \\ *Chemistry Department, Faculty of Science, Mansoura University, 35516, P. O. Box 70, Mansoura, Egypt \\ **Chemistry Department, Faculty of Science, Ochanomizu University, Japan \\ ***Chemistry Department, Faculty of Science, Niigata University, Niigata, Japan
}

\begin{abstract}
Solvent sublation has been studied for the separation and determination of trace iron(II) in various kinds of water samples. A strongly magenta-colored anionic $\left[\mathrm{Fe}(\mathrm{FZ})_{3}\right]^{4-}$ complex was formed at $\mathrm{pH} 5.0$ upon adding 3-(2-pyridyl)-5,6bis(4-phenylsulfonic acid)-1,2,4-triazine (ferrozine, FZ) to the sample solution. Tetrabutylammonium bromide (TBAB) was added in the solution to form the (TBA) $)_{4}\left[\mathrm{Fe}(\mathrm{FZ})_{3}\right]$ ion pair, and an oleic acid $(\mathrm{HOL})$ surfactant was added. Then, the $(\mathrm{TBA})_{4}\left[\mathrm{Fe}(\mathrm{FZ})_{3}\right]$ ion pairs were floated by vigorous shaking in the flotation cell and extracted into methyl isobutyl ketone (MIBK) on the surface of the aqueous solution. The iron collected in the MIBK layer was measured directly by spectrophotometry and/or flame atomic-absorption spectrophotometry. Different experimental variables that may affect the sublation efficiency were thoroughly investigated. The molar absorptivity of the $(\mathrm{TBA})_{4}\left[\mathrm{Fe}(\mathrm{FZ})_{3}\right]$ ion pair was $2.8 \times$ $10^{4} 1 \mathrm{~mol}^{-1} \mathrm{~cm}^{-1}$ in the aqueous layer. Beer's law held up to $1.0 \mathrm{mg} \mathrm{l}^{-1} \mathrm{Fe}$ (II) in the aqueous as well as in the organic layers. The adopted solvent sublation method was successfully applied for the determination of Fe(II) in natural water samples with a preconcentration factor of 200. The application was extended to determine iron in pharmaceutical samples.
\end{abstract}

(Received April 14, 2006; Accepted July 3, 2006)

\section{Introduction}

Determining the concentration distribution of soluble reactive species is the key to understanding biogeochemical processes in natural settings. Iron is one of the most reactive elements in aquatic environments, and its cycling is coupled to that of the major biogeochemical elements $(\mathrm{C}, \mathrm{O}, \mathrm{S}$ and $\mathrm{P})$ and trace elements, such as heavy metals. ${ }^{1}$ Iron is present in the hydrosphere under two oxidation states, II and III, which are thermodynamically stable under anoxic and oxic conditions, respectively. ${ }^{2}$

There are several possible strategies for enhancing the overall sensitivity for metal determination when using a metal-chelate technique. In an effort to develop a preconcentration technique for measuring $\mathrm{Fe}(\mathrm{II})$ and total iron in natural water samples, investigations were conducted concerning the use of ferroins as preconcentrating agents for iron. These techniques include solvent extraction, ion exchange and solvent sublation..$^{3-7,9}$ According to the IUPAC definition, solvent sublation is a flotation process in which the material of interest is adsorbed on the surface of gas bubbles in a liquid, and collected on an upper layer of an immiscible liquid. There is no liquid-phase mixing in the bulk of the system; as a result, recoveries can reach $100 \%$. Solvent sublation has advantages that the analytes of complexed forms can be directly extracted into a solvent by the flotation and determined in the solvent as a concentrated state by different analytical methods. The solvent should be so

$\doteqdot$ To whom correspondence should be addressed.

E-mail: magdaakl_59@hotmail.com nonvolatile that no loss occurs during the experimental procedure and gives a small background in the determination of elements by an analytical method. Schilt ${ }^{8}$ first reported the $\mathrm{Fe}(\mathrm{II})$-chelating properties of 3-(2-pyridyl)-5,6-diphenyl-1,2,4triazine (PDT). Schilt found that PDT formed a tris complex with $\mathrm{Fe}(\mathrm{II}),\left[\mathrm{Fe}(\mathrm{PDT})_{3}\right]^{2+}$. Kotsuji et al. ${ }^{9}$ developed a method for determining trace levels $(100 \mathrm{nmol} / \mathrm{kg}$ level $)$ of iron in seawater by using the solvent sublation of $\left[\mathrm{Fe}(\mathrm{PDT})_{3}\right]^{2+}$ cations with an anionic surfactant, sodium lauryl sulfate, as a collector. $\mathrm{Fe}$ (II) was concentrated into isoamyl alcohol added to the surface of the aqueous solution as foam breaker and extractant. Stookey ${ }^{10}$ first reported the $\mathrm{Fe}(\mathrm{II})$ chelating properties of 3-(2pyridyl)-5,6-bis(4-phenylsulfonic acid)-1,2,4-triazine (ferrozine, FZ), Scheme 1. Stookey found that ferrozine formed a tris complex with $\mathrm{Fe}(\mathrm{II}),\left[\mathrm{Fe}(\mathrm{FZ})_{3}\right]^{4-}$. The iron complex was magenta colored with the maximum absorbance at $562 \mathrm{~nm}$.

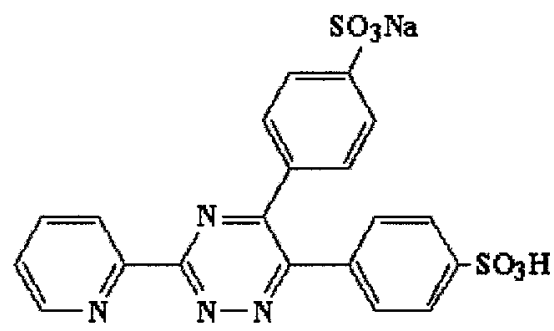

Scheme 1 3-(2-Pyridyl)-5,6-bis(4-phenylsulfonic acid)-1,2,4- triazine (FZ). 
According to Stookey, ${ }^{10}$ only $\mathrm{Co}(\mathrm{II}), \mathrm{Cu}(\mathrm{I})$ and $\mathrm{Fe}(\mathrm{II})$ can form complexes with ferrozine.

The methods for separation and preconcentration of metals by flotation and solvent sublation, followed by their spectrophotometric and/or AAS determination, have increased in popularity in recent years. ${ }^{11-19}$ A literature survey revealed that solvent sublation followed by spectrophotometric and/or AAS determination of iron(II) is rarely reported. ${ }^{9}$ Ferrozine finds its role for a direct spectrophotometric determination of $\mathrm{Fe}(\mathrm{II})$, and also gives high performance in the preconcentration of $\mathrm{Fe}(\mathrm{II})$ via its solvent sublation as ion pairs of $\left[\mathrm{Fe}(\mathrm{FZ})_{3}\right]^{4-}$ and tetrabutylammmonium ions.

In the present paper, the determination of iron by using ferrozine as a complexing agent, tetrabutylammonium $\left(\mathrm{TBA}^{+}\right)$ ion as counter ion, oleic acid (HOL) surfactant and MIBK as an organic solvent is reported. Ferrozine is more sensitive and specific than many of the reagents reported for iron(II). ${ }^{20-22} \mathrm{~A}$ number of experimental variables was evaluated, e.g. the $\mathrm{pH}$ of sample solution, the concentration of metals and ligand, the temperature, etc. In addition to measurements of iron(II) in synthetic samples, other samples such as natural water and pharmaceutical samples, were analyzed.

\section{Experimental}

\section{Chemicals and solutions}

All of the reagents and solvents were of analytical grade and were used without further treatment. Double-distilled water (DDW) was used throughout this study. An iron(III) stock solution $(1000 \mathrm{ppm})$ was prepared by dissolving $\mathrm{Fe}$ metal powder and stored at $\mathrm{pH}$ 1.0. An iron(II) stock solution (1000 ppm) was prepared by dissolving of $\left(\mathrm{NH}_{4}\right)_{2} \mathrm{Fe}\left(\mathrm{SO}_{4}\right)_{2} \cdot 6 \mathrm{H}_{2} \mathrm{O}$ in water and adjusted to $\mathrm{pH}$ 1.0. Ferrozine was purchased from Wako Chemicals Ltd. A stock solution of ferrozine $\left(4 \times 10^{-3}\right.$ mol $1^{-1}$ ) was prepared by dissolving an appropriate amount of the ligand in $0.7 \mathrm{~mol} \mathrm{l}^{-1} \mathrm{NaCl}$. A solution of $0.1 \%$ tetrabutylammonium bromide (TBAB) (Fluka) was prepared by dissolving the reagent in DDW. An oleic acid (HOL) stock solution $\left(6.3 \times 10^{-2} \mathrm{~mol} \mathrm{l}^{-1}\right)$ was prepared by dispersing $20 \mathrm{ml}$ of oleic acid (J. T. Baker Chemical) in 11 of ethanol. Solutions of other foaming reagents $(0.05 \%)$ were prepared by dissolving in appropriate solvents: Tween 80 in water, cetyltrimethylammonium bromide (CTAB) in $95 \%$ ethanol. An ascorbic acid solution (1\%) was freshly prepared just prior to use. The accuracy and precision were checked by analyzing certified reference materials viz.: phosphate 1 and phosphate 2, kindly supplied by the Authority of Nuclear Materials (Cairo, Egypt).

\section{Instrumentation}

Two types of flotation cells were used throughout. ${ }^{11-19}$ Flotation cell type 1 was a stoppered tube of $1.2 \mathrm{~cm}$ inner diameter and $29 \mathrm{~cm}$ length with a stopcock at the bottom. This cell was used to study the factors affecting the efficiency of flotation. The second type was a cylindrical tube of $6 \mathrm{~cm}$ inner diameter and $45 \mathrm{~cm}$ length with a stopcock at the bottom and a quick-fit stopper at the top. This cell was used to separate the investigated analytes from a relatively large volume.

Spectrophotometric measurements were made at $562 \mathrm{~nm}$ with a Unicam UV2 100/Vis spectrometer. A Perkin-Elmer Model 2380 atomic absorption spectrometer (USA) was used with a Pye Unicam (England) hollow-cathode lamp and a conventional $10 \mathrm{~cm}$ slit burner head for air acetylene flame. The $\mathrm{pH}$ measurements were carried out using a HANA Instrument 8519 digital $\mathrm{pH}$-meter.

\section{Analytical procedures}

In an Erlenmeyer flask, $1.0 \mathrm{ml}$ of a $2 \times 10^{-4} \mathrm{~mol} \mathrm{l}^{-1}$ ferrozine solution was added to $2 \mathrm{ml}$ an aliquot containing $2 \times 10^{-6} \mathrm{~mol} \mathrm{l}^{-1}$ $\mathrm{Fe}(\mathrm{II})$; the $\mathrm{pH}$ was adjusted to 5.0 using acetate buffer. A magenta color of $\left[\mathrm{Fe}(\mathrm{FZ})_{3}\right]^{4-}$ complex developed instantaneously. After $2 \mathrm{ml}$ of $1 \times 10^{-3} \mathrm{~mol} \mathrm{l}^{-1}$ of TBAB solution was added, the mixture was shaken well for 2 min to allow complete development of the (TBA $)_{4}\left[\mathrm{Fe}(\mathrm{FZ})_{3}\right]$ ion pair. All contents were quantitatively transferred into a flotation cell (type 1) and the volume was adjusted to $10 \mathrm{ml}$. Then, $1 \mathrm{ml}$ of 2 $\times 10^{-3} \mathrm{~mol} \mathrm{l}^{-1} \mathrm{HOL}$ was added. The flotation cell was shaken for $2 \mathrm{~min}$. Vigorous shaking of the flotation cell in the presence of a surfactant (HOL) created bubbles in the solution, which enhanced the floatability of the $(\mathrm{TBA})_{4}\left[\mathrm{Fe}(\mathrm{FZ})_{3}\right]$ ion pair. MIBK $(2 \mathrm{ml})$ was added to the solution surface and the flotation cell was shaken upside down by hand. The magenta $(\mathrm{TBA})_{4}\left[\mathrm{Fe}(\mathrm{FZ})_{3}\right]$ ion pair was quantitatively transferred into the organic layer on the solution surface. The aqueous phase was run off through the bottom of the cell. The organic layer was taken into a small vial to determine $\mathrm{Fe}$ (II) by spectrophotometric and/or AAS measurements. For a spectrophotometric determination, the thus obtained organic phase was transferred to a $1-\mathrm{cm}$ glass cell and the absorbance was measured at $562 \mathrm{~nm}$ against a reagent blank. For a flame AAS, the organic layer was aspirated directly into the flame to measure the iron concentration at $248.3 \mathrm{~nm}$. The solvent sublation efficiency $(S, \%)$ of the $\mathrm{Fe}(\mathrm{II})$ in the organic solvent was determined from the following relationship:

$$
S=\left(C_{\mathrm{o}} / C_{\mathrm{i}}\right) \times 100 \%
$$

Here, $C_{\mathrm{o}}$ and $C_{\mathrm{i}}$ denote the concentration of $\mathrm{Fe}(\mathrm{II})$ in the organic and the initial aqueous layers, respectively.

\section{Sample analysis}

Natural water samples (recovery test). Water samples were collected from the city of Mansoura, Egypt and its neighborhood. Samples were filtered using a $0.45 \mu \mathrm{m}$ pore size membrane filter to remove any suspended particulate matter and immediately treated with a few milliliters of conc. $\mathrm{HNO}_{3}$. Different concentrations of $\mathrm{Fe}(\mathrm{II})$ were introduced into a series of flotation cells, each containing 11 of a water sample. After $2 \mathrm{ml}$ of $1 \%$ ascorbic acid was added, the resulting solution was shaken well to allow complete reduction of iron into $\mathrm{Fe}(\mathrm{II})$. For any other samples, $\mathrm{Fe}$ (III) was reduced to $\mathrm{Fe}(\mathrm{II})$ by this procedure. Then, $5 \mathrm{ml}$ of $10^{-2} \mathrm{~mol} \mathrm{l}^{-1}$ ferrozine were added and each cell was shaken upside down vigorously by hand for $2 \mathrm{~min}$ to allow complexation. To each cell, $5 \mathrm{ml}$ of $1 \times 10^{-3} \mathrm{~mol} \mathrm{l}^{-1}$ TBAB was added and the mixture was shaken well. To this solution, $2 \mathrm{ml}$ of an ethanolic HOL solution $\left(2 \times 10^{-3} \mathrm{~mol} \mathrm{l}^{-1}\right)$ was added and the cell was then inverted upside down many times by hand. After that, $3 \mathrm{ml}$ of MIBK was introduced onto the surface of each cell and the cell was shaken well. The organic layer was separated to ensure a preconcentration factor of 200. This solution was then subjected directly to spectrophotometric and/or flame AAS determinations.

Certified samples. A 0.5 -g portion of each certified reference sample was completely dissolved in a Teflon beaker with a mixture of acids (45 $\mathrm{ml} \mathrm{HF}, 15 \mathrm{ml} \mathrm{H}_{2} \mathrm{SO}_{4}$ and $5 \mathrm{ml} \mathrm{HNO}_{3}$ ). After complete dissolution, the solution was evaporated untill dryness. The residue was dissolved in $20 \mathrm{ml}$ of $\mathrm{HCl} \mathrm{(1:1)} \mathrm{and}$ diluted to $100 \mathrm{ml}$ in a measuring flask using DDW. These thus prepared solutions were served for sublation analysis.

Pharmaceutical samples. Three iron containing vitamin samples were selected for the analysis of iron. Each sample was 


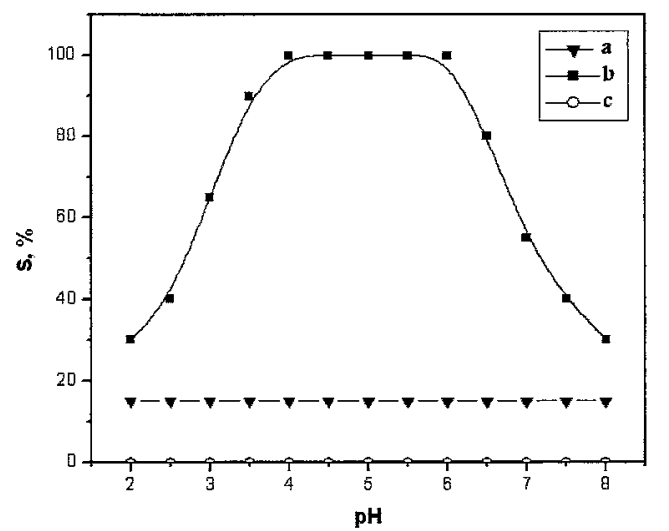

Fig. 1 Influence of $\mathrm{pH}$ on the sublation efficiency $(S, \%)$ of (a) $\mathrm{Fe}(\mathrm{II})$ in the absence of Ferrozine, (b) $(\mathrm{TBA})_{4}\left[\mathrm{Fe}(\mathrm{FZ})_{3}\right]$ ion pair and (c) $\mathrm{Fe}$ (III) $+\mathrm{FZ}$ (within $10 \mathrm{~min}$ ). $\mathrm{Fe}$ (II) and $\mathrm{Fe}$ (III), $2 \times 10^{-6} \mathrm{~mol} \mathrm{l}^{-1}$ (each); FZ, $2 \times 10^{-4} \mathrm{~mol} \mathrm{l}^{-1}$; TBAB, $1 \times 10^{-3} \mathrm{~mol} \mathrm{l}^{-1}$; HOL (1 ml), $2 \times$ $10^{-3} \mathrm{~mol} \mathrm{l}^{-1}$; MIBK, $2 \mathrm{ml}$.

treated with concentrated nitric acid on a hot-plate while avoiding violent spurting. The residue of each sample was cooled, and again 1:1 nitric acid was added. The temperature of the hot-plate was gradually increased and the solution was evaporated to dryness. The obtained residue was dissolved in nitric acid (1:1) and slowly heated for $2 \mathrm{~h}$ to procure a dry mass. Finally, the residue was dissolved in a minimum amount of nitric acid and diluted to $100 \mathrm{ml}$ with DDW. Then, $5 \mathrm{ml}$ of the thus prepared sample solutions were analyzed for iron by using the recommended general procedure.

\section{Results and Discussion}

Solvent sublation of $\mathrm{Fe}(\mathrm{II})$

Influence of $\mathrm{pH}$. A series of experiments was carried out to study the effect of the hydrogen-ion concentration on the sublation efficiency of $\mathrm{Fe}(\mathrm{II})$ in both absence and presence of ferrozine. The results are shown in Fig. 1. In the absence of ferrozine (Fig. 1, curve a), the separation efficiency is not quantitative, in which the sublation efficiency $(S, \%)$ does not exceed $15 \%$. On the other hand, Fig. 1, curve $b$ shows the effect of the $\mathrm{pH}$ on the sublation efficiency of $\mathrm{Fe}(\mathrm{II})$ in the presence of ferrozine. The shape of curve $b$ resembles that for the formation of $\left[\mathrm{Fe}(\mathrm{FZ})_{3}\right]^{4-}$ reported previously by Stookey. ${ }^{10}$ The $\left[\mathrm{Fe}(\mathrm{FZ})_{3}\right]^{4-}$ complex was quantitatively sublated as an ion pair from an aqueous solution in the $\mathrm{pH}$ range $4.0-6.5$. The optimum $\mathrm{pH}$ of the solution was selected to be as 5.0, because other metals, such as copper, cobalt and nickel, may affect the absorbance of iron(II) at higher $\mathrm{pH}$ values.

Effect of $\mathrm{Fe}$ (III). As shown in Fig. 1 (curve c), Fe(III) is not utterly sublated at any $\mathrm{pH}$. In order to prevent the reduction of $\mathrm{Fe}(\mathrm{III})$ to $\mathrm{Fe}(\mathrm{II}), 2 \mathrm{ml}$ of $0.05 \mathrm{~mol} \mathrm{l}^{-1}$ EDTA was added into the aqueous solution before adding of the Ferrozine reagent. Ferrozine has been found to reduce $\mathrm{Fe}$ (III) to $\mathrm{Fe}(\mathrm{II})$ in a variety of environmental samples unless care is taken to protectively bind $\mathrm{Fe}$ (III) (e.g. by the addition of fluoride or EDTA to the samples prior to the addition of ferrozine). ${ }^{23,24}$ To investigate this behavior on the sublation efficiency of $\mathrm{Fe}(\mathrm{II})$ using ferrozine, the sublation efficiency of a 1:1 Fe(II)-Fe(III) mixture was determined. The results indicated that the sublation efficiency did not show any deviation for up to $10 \mathrm{~min}$. After that, the sublation efficiency with respect to $\mathrm{Fe}(\mathrm{II})$ started to

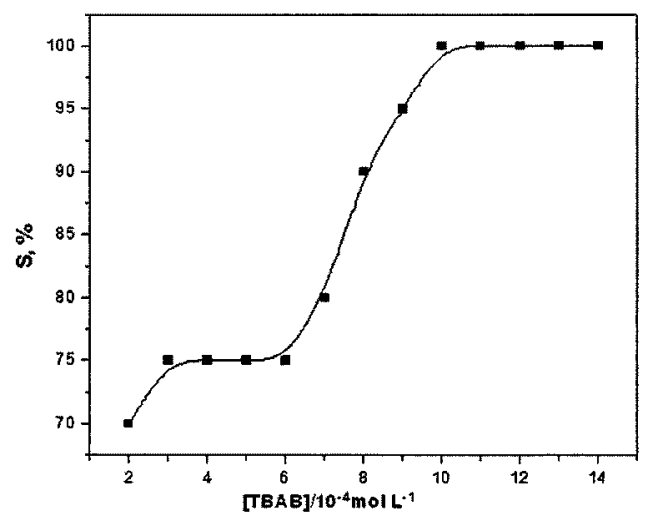

Fig. 2 Influence of the TBAB concentration on the sublation efficiency $(S, \%)$. Fe(II), $2 \times 10^{-5} \mathrm{~mol} \mathrm{l}^{-1} ; \mathrm{FZ}, 2 \times 10^{-4} \mathrm{~mol} \mathrm{l}^{-1}$, HOL (1 ml), $2 \times 10^{-3} \mathrm{~mol} \mathrm{l}^{-1}$; MIBK, $2 \mathrm{ml}$; pH 5.0.

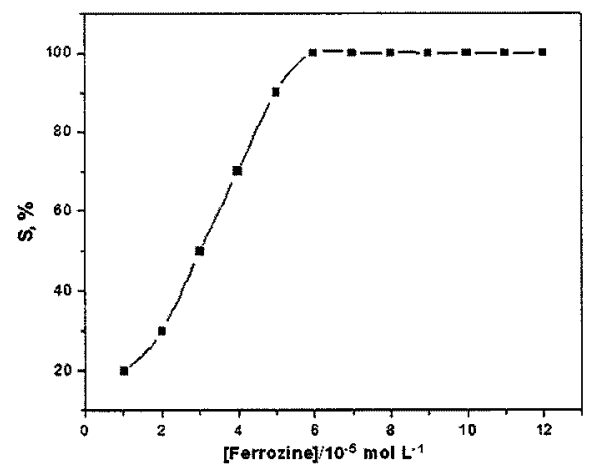

Fig. 3 Influence of the ferrozine concentration on the sublation efficiency $(S, \%)$ of $\mathrm{Fe}(\mathrm{II})$. $\mathrm{Fe}(\mathrm{II}), 2 \times 10^{-5} \mathrm{~mol} \mathrm{l}^{-1}$; TBAB, $1 \times 10^{-3}$ $\mathrm{mol} \mathrm{l}{ }^{-1}$; HOL, $2 \times 10^{-3} \mathrm{~mol} \mathrm{l}^{-1}$; MIBK, $2 \mathrm{ml}$; pH 5.0 at ca. $25^{\circ} \mathrm{C}$.

increase gradually, and reached $S=200 \%$ after $60 \mathrm{~min}$, and remained constant after that time. This means that $\mathrm{Fe}(\mathrm{III})$ was completely reduced to $\mathrm{Fe}(\mathrm{II})$ at $60 \mathrm{~min}$. Hence, better accuracy was achieved by recording the absorbance within $10 \mathrm{~min}$ of adding the ferrozine reagent.

Influence of $T B A B$ concentration. Although the anionic complex, $\left[\mathrm{Fe}(\mathrm{FZ})_{3}\right]^{4-}$, is sublated by the bulky organic cation, $\mathrm{TBA}^{+}$, sublation is not quantitative. However, by the addition of the surfactant, HOL, the complex could be quantitatively floated and extracted easily into MIBK. The solvent sublation efficiency reached $100 \%$ at $\mathrm{pH}$ 5.0. The effect of the TBAB concentration on the sublation efficiency of the complex in the presence of HOL was investigated using $2 \times 10^{-5} \mathrm{~mol} \mathrm{l}^{-1}$ (1.12 ppm) $\mathrm{Fe}(\mathrm{II})$ at $\mathrm{pH}$ 5.0. Figure 2 shows that the maximum sublation efficiency of $\left[\mathrm{Fe}(\mathrm{FZ})_{3}\right]^{4-}$ was attained when the concentration of TBAB was $\geq 1 \times 10^{-3} \mathrm{~mol} \mathrm{l}^{-1}$. Thus, $1 \times 10^{-3}$ mol $1^{-1}$ of TBAB was chosen in the present study.

Influence of ferrozine and $\mathrm{Fe}(\mathrm{II})$ concentrations. The influence of different concentrations of FZ on the sublation efficiency of $2 \times 10^{-5} \mathrm{~mol} \mathrm{l}^{-1} \mathrm{Fe}(\mathrm{II})$ using $1 \times 10^{-3} \mathrm{~mol} \mathrm{l}^{-1}$ of TBAB, $1 \mathrm{ml}$ of $2 \times 10^{-3} \mathrm{~mol} \mathrm{l}^{-1}$ of HOL and $2 \mathrm{ml}$ of MIBK at $\mathrm{pH} 5.0$ was investigated. As can be seen from Fig. 3, the quantitative sublation of $\mathrm{Fe}(\mathrm{II})$ was attained under the condition $[\mathrm{FZ}]:[\mathrm{Fe}(\mathrm{II})] \geq 3$.

Another series of experiments was conducted to sublate different concentrations of $\mathrm{Fe}(\mathrm{II})$ using $6 \times 10^{-5} \mathrm{~mol} \mathrm{l}^{-1}$ of $\mathrm{FZ}$ in the presence of $1 \times 10^{-3} \mathrm{~mol} \mathrm{l}^{-1} \mathrm{TBAB}, 1 \mathrm{ml}$ of $2 \times 10^{-4} \mathrm{~mol} \mathrm{l}^{-1}$ 


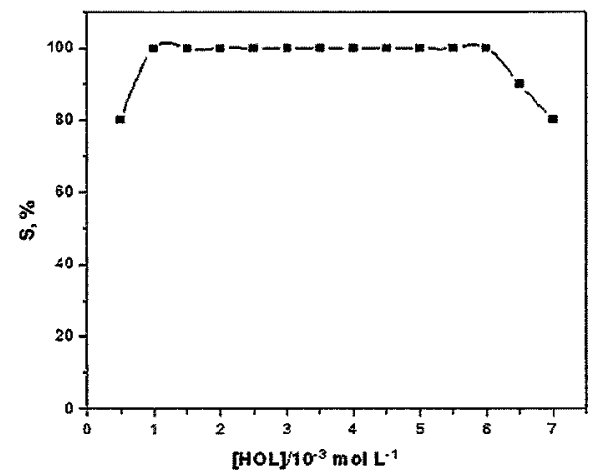

Fig. 4 Solvent sublation of the $(\mathrm{TBA})_{4}\left[\mathrm{Fe}(\mathrm{FZ})_{3}\right]$ ion pair $v s$. HOL concentration. $\mathrm{Fe}(\mathrm{II}), 2 \times 10^{-6} \mathrm{~mol} \mathrm{l}^{-1} ; \mathrm{FZ}, 2 \times 10^{-5} \mathrm{~mol} \mathrm{l}^{-1}$; TBAB, $\times 10^{-3} \mathrm{~mol} \mathrm{1}{ }^{-1} ; \mathrm{MIBK}, 2 \mathrm{ml} ; \mathrm{pH} 5$ at $25^{\circ} \mathrm{C}$.

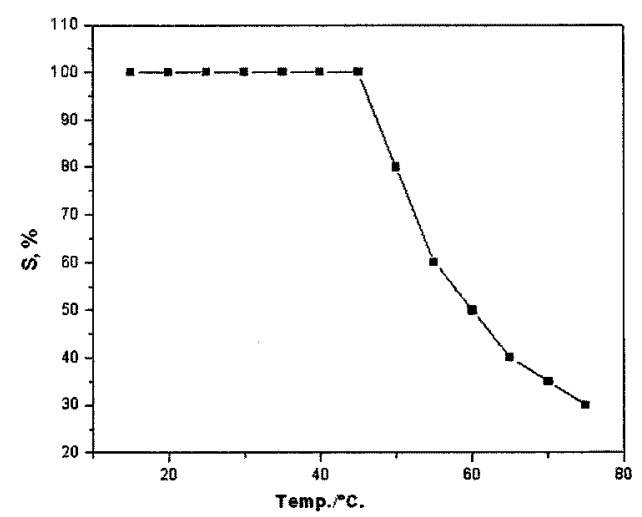

Fig. 5 Influence of the temperature on the sublation efficiency $(S$, $\%$ ) of the (TBA) $)_{4}\left[\mathrm{Fe}(\mathrm{FZ})_{3}\right]$ ion pair. $\mathrm{Fe}(\mathrm{II}), 2 \times 10^{-6} \mathrm{~mol} \mathrm{l}^{-1}$; FZ, $2 \times$ $10^{-5} \mathrm{~mol} \mathrm{l}^{-1}$; TBAB, $1 \times 10^{-3} \mathrm{~mol} \mathrm{l}^{-1}$; HOL $(1 \mathrm{ml}), 2 \times 10^{-3} \mathrm{~mol} \mathrm{l}^{-1}$; MIBK, $2 \mathrm{ml} ; \mathrm{pH} 5$ at $25^{\circ} \mathrm{C}$.

of HOL and $2 \mathrm{ml}$ of MIBK at pH 5.0. These results confirmed that quantitative sublation was obtained when $[\mathrm{Fe}]:[\mathrm{FZ}] \geq 1: 3$. In most experiments in this investigation, the concentration of FZ was chosen to be more than 10-fold that of Fe(II).

Type and amount of surfactant. The flotation and extraction of complexes into MIBK on the surface of aqueous solution in a flotation cell is enhanced by changing the complexes from hydrophilic to hydrophobic properties. The change can be done by using a surfactant. Such an enhancement can be explained as follows. The ion-pair or metal-ligand complexes are adsorbed with a surfactant and easily floated to the top of the solution by bubbling nitrogen gas or vigorous shaking. The complexes adsorbed are desorbed in an organic phase if the complexes are floated to the phase. ${ }^{25}$ A neutral $\mathrm{TBA}^{+}$ion pair of complexes can be floated and extracted into MIBK, but a surfactant has been used to improve the flotation. This is due to the fact that a surfactant not only supports an ion pair by forming foams, but can also make the surface of the ion pair hydrophobic, and hence can easily be attached to air bubbles. ${ }^{26-28}$

The effect of the type of surfactant on the efficiency of sublation was studied using anionic (HOL), non-ionic (Tween $80)$ and cationic $(\mathrm{CTAB})$ surfactants. The $(\mathrm{TBA})_{4}\left[\mathrm{Fe}(\mathrm{FZ})_{3}\right]$ ion pair was not sublated at all upon using cationic or non-ionic surfactants. On the other hand, the anionic surfactant HOL strongly increased the sublation efficiency. Such a phenomenon can be interpreted to mean that excess $\mathrm{TBA}^{+}$around the
Table 1 Influence of foreign ions on the solvent sublation efficiency of $\mathrm{Fe}$ (II)

\begin{tabular}{llr}
\hline \multicolumn{1}{c}{ Ion } & Concentration & \multicolumn{1}{c}{$S, \%$} \\
\hline None & - & $100 \pm 0.5$ \\
$\mathrm{Co}(\mathrm{II})$ & $0.10 \mathrm{mg} \mathrm{l}^{-1}$ & $101.0 \pm 0.6$ \\
$\mathrm{Ni}(\mathrm{II})$ & $0.10 \mathrm{mg} \mathrm{l}^{-1}$ & $100.8 \pm 0.1$ \\
$\mathrm{Ca}(\mathrm{II})$ & $0.5 \mathrm{mg} \mathrm{l}^{-1}$ & $100.1 \pm 0.9$ \\
$\mathrm{NO}_{3}^{-}$ & $0.1 \mathrm{mmol} \mathrm{l}^{-1}$ & $99.9 \pm 0.4$ \\
$\mathrm{NO}_{2}{ }^{-}$ & $0.1 \mathrm{mmol} \mathrm{l}^{-1}$ & $99.8 \pm 0.9$ \\
$\mathrm{PO}_{4}{ }^{3-}$ & $0.1 \mathrm{mmol} \mathrm{l}^{-1}$ & $100.0 \pm 0.7$ \\
$\mathrm{CN}^{-}$ & $0.1 \mathrm{mmol} \mathrm{l}^{-1}$ & $101.0 \pm 0.6$ \\
Tartarate & $0.1 \mathrm{mmol} \mathrm{l}^{-1}$ & $99.8 \pm 0.3$ \\
Citrate & $0.1 \mathrm{mmol} \mathrm{l}^{-1}$ & $101.0 \pm 0.4$ \\
\hline
\end{tabular}

Conditions: $\mathrm{Fe}(\mathrm{II}), 10 \mu \mathrm{g} \mathrm{l}^{-1}$; FZ, $2 \times 10^{-4} \mathrm{~mol} \mathrm{l}^{-1}$; TBAB, $1 \times 10^{-3}$ mol l-1; HOL, $4 \times 10^{-3} \mathrm{~mol} \mathrm{l}^{-1}$; MIBK, $2 \mathrm{ml}$; pH 5.0 at $c a .25^{\circ} \mathrm{C}$.

$\left[\mathrm{Fe}(\mathrm{FZ})_{3}\right]^{4-}$ complex creates ion pairs of positive charge. Therefore, the addition of an anionic surfactant improves the efficiency of sublation.

The concentration of HOL is an important parameter to improve the limit of the separation percentage. Figure 4 shows that the sublation efficiency of the $(\mathrm{TBA})_{4}\left[\mathrm{Fe}(\mathrm{FZ})_{3}\right]$ ion pair reaches its maximum $(100 \%)$ over a wide range of $\mathrm{HOL}$ concentrations. A suitable concentration $\left(2 \times 10^{-3} \mathrm{~mol} \mathrm{l}^{-1}\right)$ of HOL was selected throughout this work.

Influence of organic solvents. A proper choice of the solvent is very important to dissolve and extract the floated ion pairs into the solvent. The solvent should be lighter than an aqueous solution, i.e., with a specific gravity less than $1 \mathrm{~g} \mathrm{ml}^{-1}$, separated clearly from the aqueous phase and does not turn turbid by mixing with water. In the present study, the sublation efficiency was investigated with such solvents as benzene, MIBK, xylene and hexane. MIBK was chosen as a solvent in the present study because of the maximum absorbance and the lowest background for the investigated analyte.

Effect of temperature. The temperature effect on the sublation efficiency is depicted in Fig. 5. The sublation of $(\mathrm{TBA})_{4}\left[\mathrm{Fe}(\mathrm{FZ})_{3}\right]$ ion pair is not affected by raising the temperature up to $45^{\circ} \mathrm{C}$, above which the sublation efficiency starts to decrease. This decrease may be attributed to an instability of the ion pairs $(\mathrm{TBA})_{4}\left[\mathrm{Fe}(\mathrm{FZ})_{3}\right]$ as well as weak binding between the HOL surfactant and the ion pair species. Thus, all work was carried out at room temperature $\left(25^{\circ} \mathrm{C}\right)$.

Influence of foreign ions and ionic strength. Interference with the spectrophotometric determination of iron(II) as its ferrozine complex has been reported for copper, cobalt, and nickel. ${ }^{29}$ The effect of the above-mentioned metal ions on the sublation efficiency $(S, \%)$ of iron(II) was investigated using a standard solution to which each ion was added. The results are shown in Table 1. As can be seen, at $\mathrm{pH} 5$, only cobalt caused a slight decrease in the $S, \%$ at $0.1 \mathrm{mg} \mathrm{l}^{-1}$, but nickel and copper had no influence on the concentrations of 0.1 and $0.5 \mathrm{mg} \mathrm{l}^{-1}$, respectively. In natural water samples (seawater) the concentrations of copper, cobalt and nickel are not high enough to cause any detectable interference. In Table 1, the effects of some anionic species are also given. Nitrate, nitrite, phosphate, cyanide, tartarate and citrate did not interfere up to a concentration of $0.1 \mathrm{mmol} \mathrm{l}^{-1}$, which is rarely found in seawater (natural water).

Concerning the redox speciation of iron(II), this method is highly selective for iron(II) over iron(III). The selectivity of the method for iron(II) was confirmed by determining the iron(II) plus iron(III) concentrations throughout the entire procedure. 
Table 2 Influence of the Fe(III) concentration on the solvent sublation of $\mathrm{Fe}(\mathrm{II})$

\begin{tabular}{ccc}
\hline $\begin{array}{c}\text { Fe(II) added/ } \\
\mu \mathrm{g} \mathrm{l}^{-1}\end{array}$ & $\begin{array}{c}\text { Fe(III) added/ } \\
\mu \mathrm{g} \mathrm{l}^{-1}\end{array}$ & $\begin{array}{c}\text { Recovery, } \\
R, \%^{\mathrm{a}}\end{array}$ \\
\hline 10.0 & - & $100.0 \pm 0.2$ \\
10.0 & 10.00 & $100.0 \pm 0.5$ \\
10.0 & 100.0 & $100.0 \pm 0.1$ \\
- & 100.0 & 0.005 \\
\hline
\end{tabular}

Conditions: FZ, $2 \times 10^{-4} \mathrm{~mol} \mathrm{l}^{-1}$; TBAB, $1 \times 10^{-3} \mathrm{~mol} \mathrm{l}^{-1}$; HOL, $4 \times$ $10^{-3} \mathrm{~mol} \mathrm{l}^{-1}$; MIBK, $2 \mathrm{ml}$; pH 5.0.

a. Recovery $(R, \%)$, is calculated within 10 min after addition of ferrozine.

Table 3 Statistical evaluation for the analysis of some certified reference samples after preconcentration using the proposed solvent sublation procedure

\begin{tabular}{|c|c|c|c|c|c|}
\hline \multirow{2}{*}{$\begin{array}{c}\text { Ore } \\
\text { sample }\end{array}$} & \multicolumn{2}{|c|}{ Iron, $\%$} & \multirow{2}{*}{$s^{\mathrm{c}}$} & \multirow{2}{*}{$|t|_{1}^{d}$} & \multirow{2}{*}{ RSD, \% } \\
\hline & $\bar{X}^{\mathrm{a}}$ & $\mu^{\mathrm{b}}$ & & & \\
\hline Phosphate 1 & 1.58 & 1.56 & 0.08 & 0.56 & 1.50 \\
\hline Phosphate 2 & 1.35 & 1.34 & 0.01 & 2.24 & 3.70 \\
\hline
\end{tabular}

a. Experimental value.

b. Certified value.

c. Standard deviation.

d. $|\mathrm{t}|_{1}=2.78$ for $P=0.05$ and $n=5$ (degree of freedom, 4).

As shown in Table 2, iron(III) is not sublated at all. These results indicate that the present sublation methodology is highly selective for iron(II).

To study the effect of the ionic strength on the sublation efficiency of $\mathrm{Fe}$ (II) under the recommended conditions, sodium, magnesium and calcium as chloride and sulfate were added during sublation separation of the analyte at the recommended conditions. It was found that these salts, even up to the $0.5 \mathrm{~mol}$ $1^{-1}$ concentration level, had no effect on the solvent sublation efficiency of $\mathrm{Fe}(\mathrm{II})$.

\section{Analytical figures of merits}

The applicability of ferrozine as a complexing agent for the spectrometric determination of $\mathrm{Fe}(\mathrm{II})$ was studied in the concentration range $0.0-1000 \mu \mathrm{g} \mathrm{l}^{-1} \mathrm{Fe}(\mathrm{II})$ solution under the recommended conditions. The obtained calibration graph was a straight line passing through the origin over the concentration range mentioned above. The effective molar absorptivity of the $(\mathrm{TBA})_{4}\left[\mathrm{Fe}(\mathrm{FZ})_{3}\right]$ ion pair was $2.8 \times 10^{4} 1 \mathrm{~mol}^{-1} \mathrm{~cm}^{-1}$ in the aqueous layer. That of organic phase, with respect to the initial iron concentration in aqueous phase, was $2.1 \times 10^{6} 1 \mathrm{~mol}^{-1} \mathrm{~cm}^{-1}$. Beer's law held up to $1 \mathrm{mg} \mathrm{l}^{-1}$, in the aqueous as well as in the organic layer, with the optimum range. The limit of detection was found to be $1.8 \times 10^{-8} \mathrm{~mol} \mathrm{l}^{-1}$. Also, concerning this matter, a fixed quantity of $\mathrm{Fe}$ (II) was taken and added to different volumes of aqueous solutions. It was found that of $6.1 \times 10^{-7}$ mol $\mathrm{l}^{-1} \mathrm{Fe}(\mathrm{II})$ was quantitatively separated and determined from different volumes up to 11 . This means that $34 \mathrm{pbb}$ of Fe(II) can be safely separated and determined by such a procedure from 11 solution into $5 \mathrm{ml}$ of the organic layer.

In order to validate the proposed solvent sublation methodology, it was applied to two certified reference materials viz.: phosphate 1 and phosphate 2 . The average contents of iron $(n=5)$ in the certified reference materials are given in Table 3
Table 4 Spectrophotometric determination of $\mathrm{Fe}(\mathrm{II})$ and $\mathrm{Fe}(\mathrm{III})$ in their mixtures after solvent sublation

\begin{tabular}{lcccc}
\hline \multirow{2}{*}{ Species } & \multicolumn{2}{c}{ Concentration, ppm } & & \\
\cline { 2 - 3 } & Added & Found & & \\
& & & & \\
\hline $\mathrm{Fe}(\mathrm{II})$ & 1.12 & 1.13 & 2.50 & 100.9 \\
$\mathrm{Fe}(\mathrm{III})$ & 1.12 & 1.11 & 3.10 & 99.2 \\
$\mathrm{Fe}(\mathrm{II})$ & 2.79 & 2.80 & 1.50 & 100.4 \\
$\mathrm{Fe}(\mathrm{III})$ & 1.12 & 1.13 & 3.20 & 100.9 \\
$\mathrm{Fe}(\mathrm{II})$ & 5.58 & 5.60 & 4.50 & 100.4 \\
$\mathrm{Fe}(\mathrm{III})$ & 1.12 & 1.10 & 2.60 & 98.2 \\
$\mathrm{Fe}(\mathrm{II})$ & 27.9 & 27.8 & 0.95 & 99.6 \\
$\mathrm{Fe}(\mathrm{III})$ & 1.12 & 1.14 & 2.83 & 101.8 \\
\hline
\end{tabular}

Conditions: ascorbic acid, $0.1 \%$; FZ, $2 \times 10^{-4} \mathrm{~mol} \mathrm{l}^{-1}$; TBAB, $1 \times 10^{-3}$ mol $1^{-1}$; HOL, $4 \times 10^{-3} \mathrm{~mol} \mathrm{l}^{-1}$; MIBK, $5 \mathrm{ml}$; $\mathrm{pH} 5.0$.

Table 5 Recovery $(R, \%)$ of known $\mathrm{Fe}(\mathrm{II})$ concentrations added to different water samples

\begin{tabular}{lcccc}
\hline \multirow{2}{*}{$\begin{array}{c}\text { Water sample } \\
\text { (source) }\end{array}$} & \multicolumn{2}{c}{$\mathrm{Fe}(\mathrm{II}) / \mathrm{ppm}$} & & \\
\cline { 2 - 3 } & Added & Found $^{\mathrm{a}}$ & & \\
& & & & \\
& & & & \\
Tap water & 0.5 & 0.51 & 102 & 2.9 \\
(Mansoura City) & 1.0 & 1.03 & 103 & 3.2 \\
Nile River & 0.5 & 0.48 & 96 & 4.3 \\
(Mansoura City) & 1.0 & 0.98 & 98 & 2.4 \\
Seawater & 0.5 & 0.52 & 104 & 3.2 \\
(Ras El-Bar) & 1.0 & 1.02 & 102 & 1.3 \\
\hline
\end{tabular}

Conditions: ascorbic acid, $0.1 \%$; FZ, $2 \times 10^{-4} \mathrm{~mol}^{-1}$; TBAB, $1 \times 10^{-3}$ mol l-1 ; HOL, $4 \times 10^{-3} \mathrm{~mol} \mathrm{l}^{-1}(2 \mathrm{ml})$; MIBK, $3 \mathrm{ml}$; $\mathrm{pH} 5.0$ at $c a .25^{\circ} \mathrm{C}$. a. Mean values were obtained by spectrophotometry using five known samples.

with the precision as relative standard deviation $(\mathrm{RSD})<5 \%$. Table 3 also compares the experimental mean $(\bar{X})$ and the certified value $(\mu)$ by the $|t|_{1}$ test. From Table 4 it can be noticed that $|\mathrm{t}|_{1}=0.56$ and 2.240 for iron. This means that the null hypothesis of $|\mathrm{t}|_{1}$ for $P=0.05$ and $n=5$ is retained where the calculated experimental values of $|t|_{1}$ are less than the tabulated value $\left(|t|_{1}=2.78\right)$. This means that all preconcentrated samples are not subject to any systematic error i.e. are accurate.

\section{Application}

Determination of $\mathrm{Fe}(\mathrm{II})$ and $\mathrm{Fe}(\mathrm{III})$ in synthetic mixtures. The proposed procedure was successfully applied to two synthetic mixtures of $\mathrm{Fe}(\mathrm{II})$ and $\mathrm{Fe}(\mathrm{III})$ with different concentrations (foreign ions free). The data are presented in Table 4.

Recovery yields of iron in natural water samples. The developed procedure for the determination of $\mathrm{Fe}(\mathrm{II})$ using a sublation methodology and spectrophotometry was examined for several natural-water samples (Table 5). The recoveries of spiked known additions to different water samples lay within the range $96-104 \%$.

Analysis of pharmaceutical samples. The proposed sublation procedure was successfully applied to the determination of iron in some iron-containing pharmaceutical samples (Table 6) with satisfactory results.

\section{Conclusion}

Solvent sublation, compared with ion flotation, has an 
Table 6 Determination of iron in some pharmaceutical samples by the proposed solvent sublation technique

\begin{tabular}{|c|c|c|c|c|}
\hline \multirow{2}{*}{$\begin{array}{l}\text { Sample } \\
\text { (source) }\end{array}$} & \multicolumn{2}{|c|}{ Spectrophotometry } & \multicolumn{2}{|c|}{ FAAS } \\
\hline & $\begin{array}{l}\text { Observed } \\
\text { value }^{\mathrm{b}}\end{array}$ & RSD, \% & $\begin{array}{c}\text { Observed } \\
\text { value }\end{array}$ & RSD, $\%$ \\
\hline Theregran & 66.60 & 2.00 & 66.90 & 3.8 \\
\hline $\begin{array}{l}\text { Haematinic } \\
\text { (Squib, Egypt) }\end{array}$ & $(66.70)^{\mathrm{a}}$ & & & \\
\hline $\begin{array}{l}\text { Totavit } \\
\text { (Egyphar, Egypt) }\end{array}$ & $\begin{array}{c}18.20 \\
(18.00)^{\mathrm{a}}\end{array}$ & 3.7 & 17.80 & 3.0 \\
\hline $\begin{array}{l}\text { Haemacaps } \\
\text { (Amoun Pharm. } \\
\text { Co., Egypt) }\end{array}$ & $\begin{array}{c}349 \\
(350)^{\mathrm{a}}\end{array}$ & 2.7 & 350 & 4.6 \\
\hline
\end{tabular}

Conditions: ascorbic acid $0.1 \%$; FZ, $2 \times 10^{-4} \mathrm{~mol} \mathrm{1}^{-1}$; TBAB, $1 \times 10^{-3}$; mol l-1; HOL, $4 \times 10^{-3} \mathrm{~mol} \mathrm{l}^{-1}$; MIBK, $2 \mathrm{ml}$; pH 5.0 at $c a .25^{\circ} \mathrm{C}$. a. Calculated values ( $\mathrm{mg} /$ capsule).

b. Mean $(n=3)$.

advantage in that it allows analysis of the organic phase directly, and it is not necessary to destroy the foam (which is not always a very easy task). In the present study, traces of $\mathrm{Fe}(\mathrm{II})$ in media of diverse origin were determined by a solvent sublation methodology using an ion pair of ferrozine-Fe(II) anion and tetrabutylammonium ions for the utilization of a synergistic effect. The hydrophobic ion pairs, created by the addition of oleic acid surfactant, were floated and extracted into MIBK by vigorous shaking of the flotation cell. The iron concentrated in the organic layer was subjected directly to spectral determination without preliminary elution. This procedure was successfully applied to the analysis of various kinds of water samples spiked with known amounts of $\mathrm{Fe}(\mathrm{II})$ with a preconcentration factor of 200. Applications were, also, extended to determine iron in iron containing vitamins with good precision as $\mathrm{RSD}, \%<5$. Such results show that this is a fairly accurate and reproducible method which can be applied to similar samples.

\section{References}

1. A. Tessier and P. G. C. Campell, "Partitioning of Trace Metals in Sediment", in "Metal Speciation, Theory, Analysis and Application”, ed. J. R. Kramer and H. E. Allan, 1988, Lewis publishers, Chelsea, 183 - 199.

2. E. Viollier, P. W. Inglett, K. Hunter, A. N. Roychounhury and P. Van Cappellen, Appl. Geochem., 2000, 15, 785.
3. A. A. Schilt and P. J. Taylor, Anal. Chem., 1970, 42, 220.

4. C. D. Chriswell and A. A. Schilt, Anal. Chem., 1974, 469, 92.

5. L. P. Zang and K. Terada, Anal. Chim. Acta, 1994, 293, 311.

6. D. W. King, J. Lin, and D. R. Kester, Anal. Chim. Acta, 1991, 247, 125.

7. S. Blain and P. Teguer, Anal. Chim. Acta, 1995, 308, 425.

8. A. A. Schilt, Talanta, 1966, 13, 895.

9. K. Kotsuji, Y. Kameyama, M. Arikawa, and S. Hayashi, Bunseki Kagaku, 1977, 26, 475.

10. L. L. Stookey, Anal. Chem., 1970, 42, 779.

11. M. A. Akl, M. E. Khalifa, S. E. Ghazy, and M. M. Hassanein, Anal. Sci., 2002, 18, 1235.

12. M. E. Khalifa, M. A. Akl, and S. E. Ghazy, Chem. Pharm. Bull., 2001, 46, 664.

13. M. A. Kabil, M. A. Akl, and M. E. Khalifa, Anal. Sci., 1999, 15, 433.

14. M. A. Akl, M. A. Kabil, A. M. Abdallaha, and D. S. Ismael, Sep. Sci. Technol., 2001, 36, 2747.

15. M. A. Kabil, M. A. Akl, A. M. Abdallah, and D. S. Ismael, Anal. Sci., 2000, 16, 713.

16. M. A. Akl, M. A. Kabil, A. M. Abdallaha, and D. S. Ismael, Bull. Chem. Soc. Jpn., 2003, 76, 1543.

17. A. M. Abdallaha, M. A. Kabil, M. A. Akl, and D. S. Ismael, J. Iran. Chem. Soc., 2004, 1, 179.

18. M. A. Akl, A. A. El Asmy, and W. M. Youssef, Anal. Sci., 2005, 21, 1325.

19. M. A. Akl, D. S. Ismael, and A. A. El Asmy, Microchem. J., 2006, 83, 61.

20. S. E. Ghazy and M. A. Kabil, Bull. Chem. Soc. Jpn., 1994, 76, 2098.

21. S. J. Chalk and J. F. Tyson, Anal. Chem., 1994, 66, 660.

22. S. W. Kang, T. Sakai, N. Ohino, and K. Ida, Anal. Chim. Acta, 1992, 261, 197.

23. N. Demirhan and F. T. Elmali, Turk. J. Chem., 2003, 27, 315.

24. Y. Erel, S. O. Pehkonen, and M. R. Hoffmann, Environ. Sci. Technol., 1992, 26, 1731.

25. R. B. Grieves, "Adsorptive Bubble Separation Methods", in "Treatise on Analytical Chemistry", ed. P. J. Elving, E. Grushka, and I. M. Kolthoff, 1982, Vol. 5, Part I, John Wiley \& Sons, New York, 375 - 436.

26. M. Aoyama, T. Hobo, and S. Suzuki, Anal. Chim. Acta, 1983, 153, 291.

27. S. Nakashima, Anal. Chem., 1979, 51, 654.

28. L. M. Cabezon, M. Caballero, R. Cela, and J. A. PerezBustamante, Talanta, 1984, 31, 597.

29. G. Zhuang, Z. Yi, R. A. Duce, and P. R. Brown, Nature, 1992, 355, 537. 